\title{
Dipodascus tetrasporeus sp. nov., an ascosporogenous yeast isolated from deep-sea sediments in the Japan Trench
}

\author{
Takahiko Nagahama, ${ }^{1}$ Mohamed Ahmed Abdel-Wahab, ${ }^{1}$ Yuichi Nogi, ${ }^{1}$ \\ Masayuki Miyazaki, ${ }^{1}$ Katsuyuki Uematsu, ${ }^{2}$ Makiko Hamamoto ${ }^{3}$ \\ and Koki Horikoshi ${ }^{1}$ \\ ${ }^{1}$ Extremobiosphere Research Center, Japan Agency for Marine-Earth Science and Technology \\ (JAMSTEC), 2-15 Natsushima-cho, Yokosuka 237-0061, Japan \\ ${ }^{2}$ Marine Technology Center, JAMSTEC, 2-15 Natsushima-cho, Yokosuka 237-0061, Japan \\ ${ }^{3}$ Department of Life Sciences, School of Agriculture, Meiji University, 1-1 Higashi Mita, Tama-ku, \\ Kawasaki 214-8571, Japan
}

Correspondence

Takahiko Nagahama

nagahama@jamstec.go.jp

\begin{abstract}
Dipodascus tetrasporeus sp. nov. is described as a novel yeast species in the family
Dipodascaceae to accommodate an isolate recovered from sediments collected on the deep-sea floor in the north-western Pacific Ocean. In the clade comprising the genera Dipodascus,

Galactomyces and Geotrichum, this is the only species that forms asci that bear four ascospores. The ascospore is surrounded by an irregular exosporium wall, similar to what is observed in the genus Galactomyces, but they are released by rupture, which is characteristic of Dipodascus and not Galactomyces. D. tetrasporeus is remarkably divergent ( $>10 \%$ difference) in its D1/D2 26S rDNA sequence from any other known species. Although maximum-likelihood analysis of combined 18S rDNA and D1/D2 26S rDNA sequences cannot elucidate a reliable position for this species, it was placed among Geotrichum carabidarum, Geotrichum cucujoidarum, Geotrichum fermentans and Geotrichum histeridarum, which also have morphological and physiological affinity with the species. The species is homothallic. The type strain of Dipodascus tetrasporeus sp. nov. is strain SY $-277^{\top}\left(=\operatorname{NBRC} 103136^{\top}=\right.$ CBS $\left.10071^{\top}\right)$.
\end{abstract}

According to Kurtzman \& Fell (1998), ascomycetous yeastlike fungi characterized by the presence of arthroconidia were assigned to the genus Geotrichum Link: Fries, with their teleomorphic state in the genera Dipodascus and Galactomyces (de Hoog et al., 1998a, b, c). Recently, these taxa were subdivided into two distinct groups. Group 1 includes the genera Dipodascus and Galactomyces, with Geotrichum anamorphs, and group 2 consists of Magnusiomyces, with Saprochaete anamorphs (de Hoog \& Smith, 2004). The two groups are well separated phylogenetically, based on $18 \mathrm{~S}$ rDNA sequences and $18 \mathrm{~S}$ rRNA secondary structure (Ueda-Nishimura \& Mikata, 2000), 26S rDNA sequences (Kurtzman \& Robnett, 1998), internal transcribed spacer (ITS) and 5.8S rDNA sequences (de Hoog \& Smith, 2004) and morphological characteristics (de Hoog et al., 1986). Species of the teleomorphic genus Dipodascus are characterized by multispored asci contain-

Abbreviations: ITS, internal transcribed spacer; ML, maximum likelihood. The GenBank/EMBL/DDBJ accession number for the region covering the 18S rDNA and the 26S rDNA D1/D2 domain of D. tetrasporeus SY$277^{\top}$ is $A B 300502$. ing eight or more ascospores, whereas species of Galactomyces and Magnusiomyces contain one (or rarely two) and four ascospores, respectively (de Hoog \& Smith, 2004). At present, the genus Dipodascus includes six species, namely Dipodascus aggregatus, D. albidus, D. armillariae, D. australiensis, D. geniculatus and D. macrosporus.

During a survey of cold-seep microbial communities of the deep-sea floor along the landward slope of the northern Japan Trench, we isolated some yeasts from sediment samples. The Japan Trench arose from the subduction of the Pacific plate under the North American plate and is well known as the site of the deepest chemosynthesis-based communities, originating from cold methane seeps (Fujikura et al., 1999). One yeast isolate possessed characters typical of the genus Geotrichum Link: Fries, whereas the others were identified as Aureobasidium pullulans, Candida pseudolambica and Rhodotorula mucilaginosa, which have often been found in deep-sea environments around the north-western Pacific Ocean (Nagahama, 2006). On the basis of $18 \mathrm{~S}$ rDNA and 26S rDNA D1/D2 region sequences, as well as morphological 
and physiological features, strain SY- $277^{\mathrm{T}}$ is described as a member of a novel species, which we name Dipodascus tetrasporeus sp. nov.

\section{Isolation and physiological characterization}

Strain SY $-277^{\mathrm{T}}$ was isolated from sediment collected from a site about $27 \mathrm{~km}$ offshore at a depth of $1763 \mathrm{~m}$ in the Japan Trench $\left(39^{\circ} 19.2359^{\prime} \mathrm{N} 142^{\circ} 52.5384^{\prime}\right.$ E) on 14 June 2002. Sampling was performed by means of a sampling system that prevents contamination by open water, as described previously (Nagahama et al., 2001a). At the sampling site, some deep-sea zoobenthos such as sea anemones, sponges, starfishes and some kinds of fishes such as eels and chimaeriformes were found. In particular, many ophiuroids were observed to be spread out over the neighbourhood of the sampling sites.

Yeast strains were characterized morphologically and physiologically using standard methods, with some modifications (Yarrow, 1998). Assimilation of nitrogen compounds was examined on solid media using a starved inoculum (Nakase \& Suzuki, 1986). Vitamin requirements were investigated according to the method of Komagata \& Nakase (1967). The DNA base composition was determined using the HPLC method of Tamaoka \& Komagata (1984).

\section{DNA sequencing and phylogenetic analysis}

DNA extraction for PCR was performed using a QIAamp DNeasy Tissue kit (Qiagen) with some modifications (Nagahama et al., 2001b) or a Microbial DNA Extraction kit (MOBIO) according to the manufacturer's instructions. The primers used for amplification and sequencing of the $18 \mathrm{~S}$ rDNA, 5.8S rDNA and ITS regions were those described by White et al. (1990); the primers for the D1/ D2 region of the 26S rDNA were those described by Fell et al. (2000).

Sequences were aligned using CLUSTAL w 1.81 (Thompson et al., 1994) and the alignment was optimized manually. Positions where one or more species contained a length mutation and/or ambiguously aligned regions were excluded from subsequent phylogenetic analyses.

Nucleotide sequence phylogenies were derived using PAUP ${ }^{\star}$ 4.0b10 (Swofford, 1998). Maximum-likelihood (ML) analyses (Felsenstein, 1981) were performed using heuristic searches with random stepwise addition of 100 replicates and tree bisection-reconnection (TBR) rearrangements. The optimal model of nucleotide evolution for the ML analyses was determined using hierarchical likelihood ratio tests as implemented in MODELTEST 3.7 (Posada \& Crandall, 1998). The model selected as the best fit for the combined dataset of $18 \mathrm{~S}$ and $26 \mathrm{~S} \mathrm{rDNA}$ was $\operatorname{TrN}+\mathrm{I}+\mathrm{G}$. For the bootstrap analyses (Felsenstein, 1985), 250 replicates were generated with five random additions and TBR. A posteriori probabilities were obtained by using Bayesian phylogenetic inference using the program MRBAYES 3.1.2
(Huelsenbeck \& Ronquist, 2001; Ronquist \& Huelsenbeck, 2003) with the GTR $+\mathrm{I}+\mathrm{G}$ model determined by using Mrmodeltest 2.2 (Nylander, 2004). Maximum-parsimony (MP) trees were obtained by 100 random addition heuristic search replicates using PAUP and 1000 bootstrap replicates were performed employing five random addition heuristic searches.

\section{Species assignment and evolutionary position of $S Y-277^{\top}$ among species related to genus Geotrichum}

We sequenced a region comprising the $18 \mathrm{~S}$ rDNA, ITS1, 5.8S rDNA, ITS2 and D1/D2 of the 26S rDNA for strain SY- $277^{\mathrm{T}}$. Each sequence was aligned with those of species in the genus Geotrichum Link: Fries and related species from public databases (Table 1). Because alignments of $18 \mathrm{~S}$ rDNA and D1/D2 were partly ambiguous owing to many length mutations, we edited the ambiguous regions manually and then removed unalignable sites from the $18 \mathrm{~S}$ rDNA and D1/D2 sequences. In the end, we used 1326 $18 \mathrm{~S}$ rDNA and 319 D1/D2 nucleotide sites for the following analyses. Reliable alignments could not be obtained for the ITS/5.8S rDNA region, in part due to the paucity of available ITS1 sequences for species of Geotrichum (de Hoog \& Smith, 2004).

We constructed phylogenetic trees from combined $18 \mathrm{~S}$ rDNA and D1/D2 26S rDNA sequences using Saccharomyces cerevisiae and Schizosaccharomyces pombe as outgroups (Fig. 1). Species of Geotrichum formed two clades corresponding to groups 1 and 2 proposed by UedaNishimura \& Mikata (2000). Whereas group 2 was well supported statistically, group 1 and internal branches near the common node were not. These behaved as sister groups in this study, as well as in previous studies (Suh \& Blackwell, 2006; Ueda-Nishimura \& Mikata, 2000; Kurtzman \& Robnett, 1998), whereas they were reported to be phylogenetically divergent in a broader context (de Hoog \& Smith, 2004). Subclades containing three species of Galactomyces and the three Dipodascus species $D$. albidus, D. australiensis and D. geniculatus were clearly distinguished from the other species of group 1 .

Strain SY $-277^{\mathrm{T}}$ was placed among Geotrichum carabidarum, Geotrichum cucujoidarum, Geotrichum fermentans and Geotrichum histeridarum, but the grouping of strain SY- $277^{\mathrm{T}}$ with Geotrichum species was weakly supported by bootstrap resampling. In addition, the shortest pairwise distances calculated between the sequences of strain SY$277^{\mathrm{T}}$ and the nine closest species were to D. macrosporus and Geotrichum klebahnii, which are not sister taxa of strain SY $-277^{\mathrm{T}}$ in Fig. 1. Strain SY $-277^{\mathrm{T}}$ was closest to $D$. macrosporus in $18 \mathrm{~S}$ rDNA sequence $(97.5 \%)$ and to $G$. klebahnii in $26 \mathrm{~S}$ rDNA sequence $(89.7 \%)$. Differences of three to six substitutions in the D1/D2 region are often interpreted as representing the critical boundary between conspecificity and non-conspecificity. In the present case, a difference in excess of $10 \%$ between strain SY $-277^{\mathrm{T}}$ and 
Table 1. Accession numbers of $18 \mathrm{~S}$ and $26 \mathrm{~S}$ rDNA sequences used in this study

\begin{tabular}{|c|c|c|c|c|}
\hline \multirow[t]{2}{*}{ Species } & \multicolumn{2}{|c|}{$18 S$ rDNA } & \multicolumn{2}{|c|}{$26 \mathrm{~S}$ rDNA } \\
\hline & Strain & Accession no. & Strain & Accession no. \\
\hline Dipodascus aggregatus & IFO $10816^{\mathrm{T}}$ & AB000645 & NRRL Y-17564 ${ }^{\mathrm{T}}$ & U40120 \\
\hline Dipodascus albidus & IFO 1984 & AB000642 & NRRL Y-12859 $9^{\mathrm{T}}$ & U40081 \\
\hline Dipodascus armillariae & IFO 10804 & AB000639 & NRRL Y-17580 & U40093 \\
\hline Dipodascus australiensis & IFO $10805^{\mathrm{T}}$ & AB000643 & NRRL Y-17565 ${ }^{\mathrm{T}}$ & U40100 \\
\hline Dipodascus geniculatus & IFO $10806^{\mathrm{T}}$ & AB000644 & NRRL Y-17628 ${ }^{\mathrm{T}}$ & U40130 \\
\hline Dipodascus macrosporus & IFO $10807^{\mathrm{T}}$ & AB000640 & NRRL Y-17586 ${ }^{\mathrm{T}}$ & U40121 \\
\hline Dipodascus tetrasporeus sp. nov. & SY $-277^{\mathrm{T}}$ & AB300502 & SY $-277^{\mathrm{T}}$ & AB300502 \\
\hline Galactomyces citri-aurantii & IFO 10822 & AB000665 & NRRL Y-17913 ${ }^{\mathrm{T}}$ & U84233 \\
\hline Galactomyces geotrichum & IFO $9541^{\mathrm{T}}$ & AB000647 & NRRL Y-17569 & U40118 \\
\hline Galactomyces reessii & IFO $10823^{\mathrm{T}}$ & AB000646 & NRRL Y-17566 ${ }^{\mathrm{T}}$ & U40111 \\
\hline Geotrichum carabidarum & NRRL Y-27727 ${ }^{\mathrm{T}}$ & AY520162 & NRRL Y-27727 ${ }^{\mathrm{T}}$ & AY520292 \\
\hline Geotrichum cucujoidarum & NRRL Y-27731 ${ }^{\mathrm{T}}$ & AY520175 & NRRL Y-27731 ${ }^{\mathrm{T}}$ & AY520305 \\
\hline Geotrichum fermentans & IFO $1199^{\mathrm{T}}$ & AB000651 & NRRL Y-17567 ${ }^{\mathrm{T}}$ & U40117 \\
\hline Geotrichum histeridarum & NRRL Y-27729 & AY520227 & NRRL Y-27729 ${ }^{\mathrm{T}}$ & AY520357 \\
\hline Geotrichum klebahnii & IFO $10826^{\mathrm{T}}$ & AB000641 & NRRL Y-17568 ${ }^{\mathrm{T}}$ & U40114 \\
\hline Magnusiomyces capitatus & IFO 10820 & AB000650 & NRRL Y-17686 ${ }^{\mathrm{T}}$ & U40084 \\
\hline Magnusiomyces ingens & JCM $9471^{\mathrm{T}}$ & $\mathrm{AB} 018130$ & NRRL Y- $17630^{\mathrm{T}}$ & $\mathrm{U} 40127$ \\
\hline Magnusiomyces magnusii & IFO 10808 & AB000653 & NRRL Y-17563 & U40097 \\
\hline Magnusiomyces ovetensis & IFO 1201 & AB000657 & NRRL Y-17574 ${ }^{\mathrm{T}}$ & U40116 \\
\hline Magnusiomyces spicifer & IFO $10809^{\mathrm{T}}$ & AB000649 & NRRL Y-17578 ${ }^{\mathrm{T}}$ & U40115 \\
\hline Magnusiomyces tetrasperma & IFO $10810^{\mathrm{T}}$ & AB000654 & NRRL Y-7288 ${ }^{\mathrm{T}}$ & U40086 \\
\hline Saprochaete fragrans & IFO $10825^{\mathrm{T}}$ & AB000656 & NRRL Y-17571 ${ }^{\mathrm{T}}$ & U40119 \\
\hline Arxula adeninivorans & IFO $10858^{\mathrm{T}}$ & AB000659 & NRRL Y-1769 & U40094 \\
\hline Arxula terrestris & IFO $10828^{\mathrm{T}}$ & AB000663 & NRRL Y-17704 ${ }^{\mathrm{T}}$ & U40103 \\
\hline Candida allociferrii & IFO 10193 & AB000658 & IFO $10194^{\mathrm{T}}$ & AB041003 \\
\hline Stephanoascus farinosus & IFO $10873^{\mathrm{T}}$ & AB000660 & NRRL Y-17593 ${ }^{\mathrm{T}}$ & U40132 \\
\hline Stephanoascus smithiae & IFO $10879^{\mathrm{T}}$ & AB000661 & NRRL Y-17849 & U76531 \\
\hline Schizosaccharomyces pombe & NRRL Y-12796 ${ }^{\mathrm{T}}$ & AY046272 & NRRL Y-12796 ${ }^{\mathrm{T}}$ & AY048171 \\
\hline Saccharomyces cerevisiae & Unknown & M27607 & NRRL Y-12632 ${ }^{\mathrm{T}}$ & AY048154 \\
\hline
\end{tabular}

any of its nearest relatives provides strong evidence that the strain represents an independent species, D. tetrasporeus. However, the phylogenetic placement of the novel species was unclear in this study because the relationship between it and neighbouring Dipodascus species is not statistically robust. Multigene analyses (Kurtzman \& Robnett, 2003) may be useful in resolving this matter in future.

\section{Morphological and physiological characteristics}

Since de Hoog \& Smith (2004) assigned four-spored species of Dipodascus to the genus Magnusiomyces in accordance with their molecular divergence, the genus Dipodascus consists only of species having asci that contain between eight and more than 100 ascospores (de Hoog \& Smith, 2004). Group 1, which comprises species of the genera Dipodascus and Galactomyces as well as their anamorphs in the genus Geotrichum, was more divergent than group 2 in terms of morphological characteristics. Our phylogenetic analysis places D. tetrasporeus in group 1 . The novel species is of special interest in view of the unique combination of characters that it possesses. Reproduction involves the formation of arthroconidia (Fig. 2a) as well as occasional buds or blastoconidia (Fig. 2b), as observed also in Geotrichum fermentans and Geotrichum cucujoidarum (Table 2). The three blastoconidiogenous species form a separate subclade (Fig. 1). D. tetrasporeus forms asci that contain four spores, a unique character within group 1 species, although it is widespread among ascosporic yeasts including the group 2 (Magnusiomyces) species. Here, the ascospores were globose or subglobose and were surrounded by an irregular exosporium wall (Fig 2b, c, f), typical of those observed in species of Galactomyces, which is phylogenetically divergent from D. tetrasporeus (Fig. 1). Moreover, the ascospores of the novel species have a gelatinous coating (Fig 2c, f) similar to that observed in species of Dipodascus and Magnusiomyces and, as observed in those species, the asci of $D$. tetrasporeus release the ascospores through rupture of persistent walls (Fig 2b, e).

D. tetrasporeus is also unusual from the physiological standpoint in its fermentation ability, which is rare among Dipodascus species (de Hoog et al., 1998a; de Hoog \& Smith, 2004). In group 1 species, this ability is found in Geotrichum species such as Geotrichum carabidarum, Geotrichum fermentans, Geotrichum histeridarum and Geotrichum klebahnii and some species of Galactomyces. 


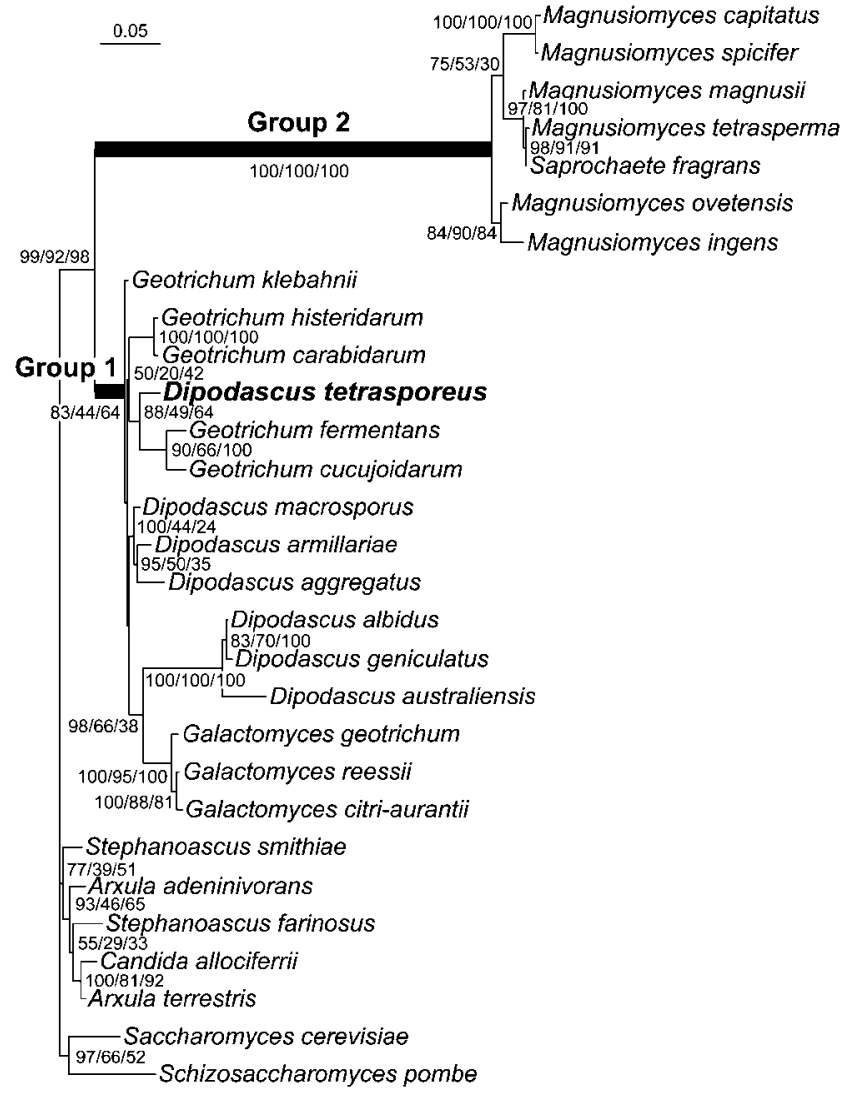

Fig. 1. Phylogenetic relationships between Dipodascus tetrasporeus sp. nov. SY- $277^{\top}$ and related species, based on nucleotide sequences of the $18 \mathrm{~S}$ rDNA and the D1/D2 region of the $26 \mathrm{~S}$ rDNA. Details of strain names and sequence accession numbers are given in Table 1. The ML tree was constructed as described in the text. Numbers are confidence values for nodes supported by $50 \%$ or more (values represent posterior probabilities in a Bayesian analysis/bootstraps for maximum-likelihood analysis with 250 replicates/bootstraps for maximum-parsimony analysis with 1000 replicates). Groups 1 and 2 are as defined by UedaNishimura \& Mikata (2000). Bar, 0.05 substitutions per site.

In particular, Geotrichum fermentans, Geotrichum klebahnii and D. tetrasporeus were similar in their ability to ferment both glucose and galactose. Furthermore, Geotrichum klebahnii is physiologically similar to D. tetrasporeus in being able to grow on vitamin-free medium and in not utilizing cellobiose as a carbon source. D. tetrasporeus can be differentiated from other species of group 1 by the absence of growth on D-mannitol and D-glucitol (Table 2), which are otherwise utilized by group 2 species. The novel species produces a fruity odour when growing in $2 \%$ malt extract (ME) medium or $4 \%$ malt extract $/ 0.5 \%$ yeast extract (MEYE) medium, as reported for Geotrichum fragrans and Galactomyces geotrichum (de Hoog et al., 1998b, c).

Owing to the lack of phylogenetic robustness among group 1 species, it may be difficult to speculate on the evolutionarily origin of the morphological traits of $D$. tetrasporeus. Distinctive characters such as the four-spored asci and the Galactomyces-type ascospores are shared with the more phylogenetically divergent species. We presume that it might be evidence that the novel species retains character states that are ancestral for group 1, although convergent appearance cannot be ruled out.

The description of $D$. tetrasporeus calls for the emendation of the description of the genus Dipodascus, although further changes may be required as a more definitive phylogenetic placement of the species becomes possible. The availability of only a single isolate from a deep-sea sediment cannot be viewed as evidence that this is the true habitat of the species, although the ability to grow at very low temperatures $\left(<4{ }^{\circ} \mathrm{C}\right)$ could be regarded as a relevant property. Psychrotolerance was common among the other yeast species isolated from same sampling area $(A$. pullulans, C. pseudolambica and R. mucilaginosa) around the north-western Pacific Ocean (Nagahama, 2006). A. pullulans and R. mucilaginosa have also been reported from PCR-based or culture-based studies in deep-sea hydrothermal vents (Edgcomb et al., 2002; Gadanho \& Sampaio, 2005; López-García et al., 2007). Among relatives of $D$. tetrasporeus, three Geotrichum species, Geotrichum carabidarum, Geotrichum cucujoidarum and Geotrichum histeridarum, were discovered in association with beetle guts (Suh \& Blackwell, 2006). Although we did not collect benthic invertebrates at the sampling site visited on this cruise, it may be that D. tetrasporeus is associated with them.

\section{Genus Dipodascus de Lagerheim emend. Nagahama et Abdel-Wahab}

Asci hyaline, subspherical to broadly ellipsoidal, cylindrical to tubular or acicular, containing four to more than 100 ascospores. Ascospores globose to ellipsoidal or cylindrical, hyaline, smooth-walled, each with an even, gelatinous coat, occasionally with an irregular exosporium similar to those found in species of Galactomyces. This description is a partial revision of that of de Hoog \& Smith (2004).

\section{Latin diagnosis of Dipodascus tetrasporeus Nagahama et Abdel-Wahab sp. nov.}

Cultura in agaro malti post dies $10\left(20{ }^{\circ} \mathrm{C}\right)$ plana, sicca, capillata, candida, centralia pulveracea et intumescens. Hyphae ad 3-5 $\mathrm{mm}$ latis, apicibus rotundatis, in arthroconidia cylindrica fragmentata $(2.5-4.0 \times 5.0-36.0 \mu \mathrm{m})$. Gametangia prope septa hypharum utrinque vel ex hyphis separatus. Asci sphaeroidei vel late ellipsoidei, 5-10 ×6$14 \mu \mathrm{m}, 1-4$ ascosporas continentes. Ascosporae late ellipsoideae, $3.0-5.0 \mu \mathrm{m}$ diametro, exosporio irregulariter inflato. Glucosum et galactosum fermentantur. Sucrosum, maltosum, lactosum, raffinosum, melibiosum non fermentantur. Glucosum, galactosum, L-sorbosum, D-xylosum, D-arabinosum (exiguum), D-ribosum (exiguum), ethanolum, glycerolum, 

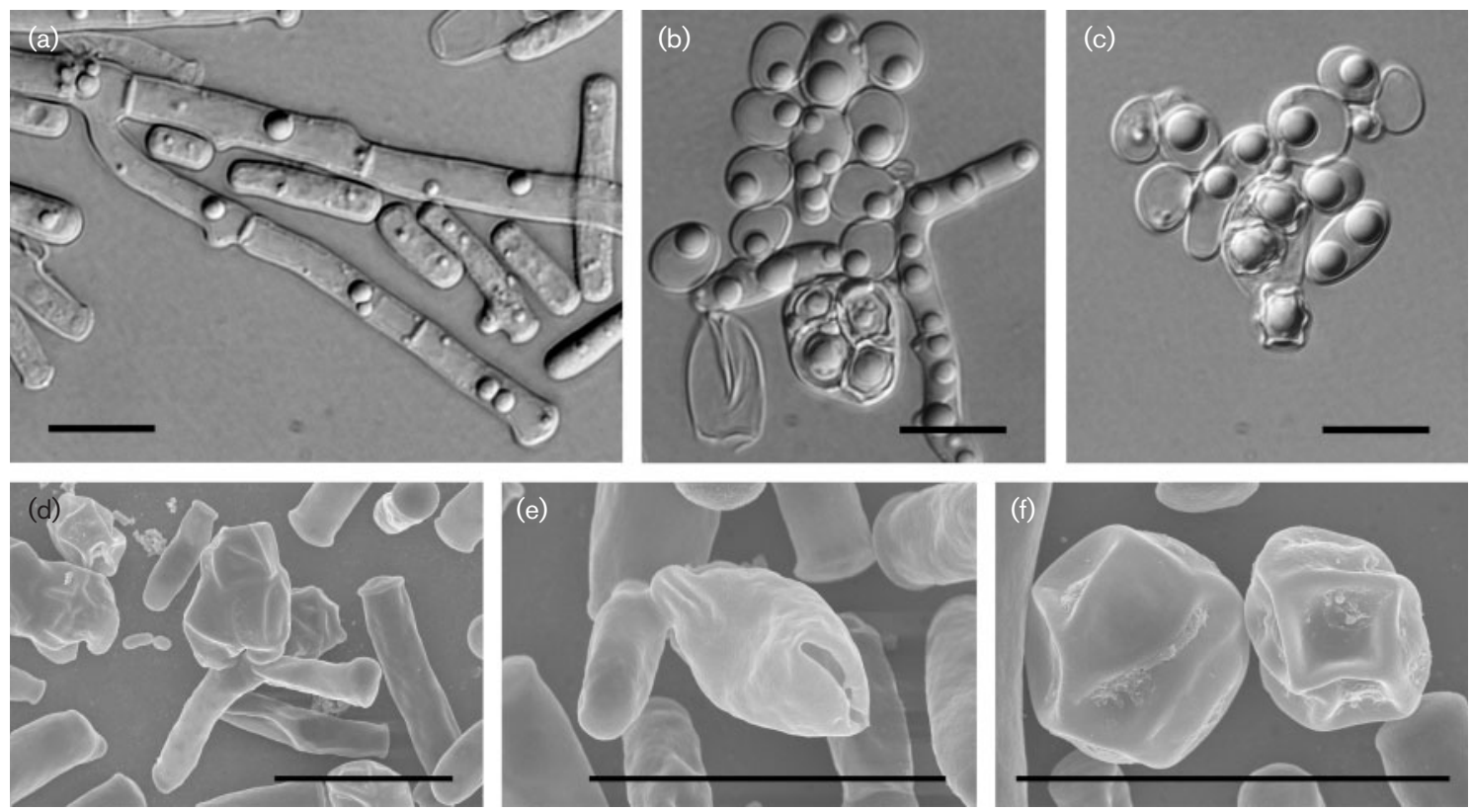

Fig. 2. (a-c) Photomicrographs of strain $S Y-277^{\top}$ after 10 days. Bar, $10 \mu \mathrm{m}$. (a) Branching hyphae and cylindrical arthroconidia (on MEYE agar). (b) Blastoconidia, an ascus with four ascospores and an empty ascus after rupture (on ME agar). (c) Ascospores with an irregular exosporium and sheath, being released from asci (on MEYE agar). (d-f) Scanning electron micrographs of strain SY-277 ${ }^{\top}$ on MEYE agar after 1 month of culture. (d) Ascus on arthroconidia and ascospores; (e) ruptured hole of empty ascus; ( $f$ ) ascospores surrounded by an exosporium with gelatinous substance.

glucono- $\beta$-lactonum, acidum DL-lacticum, acidum succinicum et acidum D-galacturonicum assimilantur, at non sucrosum, maltosum, cellobiosum, trehalosum, lactosum, melibiosum, raffinosum, melezitosum, inulinum, amylum solubile, Larabinosum, L-rhamnosum, erythritolum, ribitolum, galactitolum, D-mannitolum, D-glucitolum, methylum $\alpha$-D-glucosi- dum, salicinum, acidum 2-ketogluconicum, acidum 5ketogluconicum, inositolum, acidum citricum nec acidum Dglucuronicum. Ethylaminum, lysinum et cadaverinum assimilantur, at non kalium nitricum nec natrium nitrosum. Vitamina externa ad crescentiam non necessaria sunt. $\mathrm{G}+\mathrm{C}$ acidi deoxyribonucleati $40.7 \mathrm{~mol} \%$ (per HPLC).

Table 2. Differentiating characteristics of $D$. tetrasporeus sp. nov. and relatives

Species: 1, D. tetrasporeus (strain SY-277 ${ }^{\mathrm{T}}$ ); 2, Geotrichum klebahnii; 3, D. macrosporus; 4, D. armillariae; 5, Geotrichum carabidarum; 6, Geotrichum histeridarum; 7, Geotrichum fermentans; 8, Geotrichum cucujoidarum. +, Positive; -, negative; d, delayed positive; w, weak; v, variable depending on the strain.

\begin{tabular}{|c|c|c|c|c|c|c|c|c|}
\hline Characteristic & 1 & 2 & 3 & 4 & 5 & 6 & 7 & 8 \\
\hline \multicolumn{9}{|c|}{ Pairwise sequence similarity with strain SY $-277^{\mathrm{T}}$} \\
\hline $26 \mathrm{~S}$ rDNA & $(100)$ & 89.7 & 88.7 & 87.9 & 86.1 & 86.1 & 81.3 & 79.5 \\
\hline $18 \mathrm{~S}$ rDNA & $(100)$ & 97.2 & 97.5 & 96.6 & 95.3 & 95.1 & 94.6 & 94.6 \\
\hline Fermentation of glucose & + & + & - & - & $\mathrm{d}$ & $d / w$ & + & - \\
\hline Fermentation of galactose & + & $\mathrm{w} /-$ & - & - & - & - & + & - \\
\hline Growth in vitamin-free medium & + & + & + & + & - & - & + & + \\
\hline \multicolumn{9}{|l|}{ Growth on sole carbon compounds } \\
\hline Cellobiose & - & - & + & + & - & - & + & + \\
\hline D-Mannitol & - & + & + & + & $\mathrm{w} /-$ & + & + & + \\
\hline D-Glucitol & - & + & + & $\mathrm{V}$ & $\mathrm{w}$ & $+/ \mathrm{d}$ & + & + \\
\hline Number of ascospores per ascus & $1-4$ & - & $10-30$ & $4-12$ & - & - & - & - \\
\hline Presence of blastoconidia & + & - & - & - & - & - & + & + \\
\hline
\end{tabular}


Typus stirps SY- $277^{\mathrm{T}}$ ex sedimentum, fossa Japana, Oceanus Pacificus, isolata est. In collectionibus culturarum quas NITE Biological Resource Center, Kisarazu, Chiba sustentant, no. NBRC $103136^{\mathrm{T}}\left(=\mathrm{CBS} 10071^{\mathrm{T}}\right)$ deposita est.

\section{Description of Dipodascus tetrasporeus Nagahama et Abdel-Wahab sp. nov.}

Dipodascus tetrasporeus (te.tra.spo're.us. Gr. adj. tetra four; Gr. n. spora a seed and, in biology, a spore; N.L. masc. adj. tetrasporeus with four spores, representing the formation of four ascospores per ascus).

After 10 days on MEYE agar at $20{ }^{\circ} \mathrm{C}$, colonies are 25 $30 \mathrm{~mm}$ in diameter, white, flat, dry, centrally powdery and swelling, with finely hairy margins. Hyphae are $3-5 \mu \mathrm{m}$ wide, with rounded apices, and with some basitonous branchings, with slight differentiation between main and lateral branches, branches soon disarticulating into cylindrical arthroconidia $(2.5-4.0 \times 5.0-36.0 \mu \mathrm{m})$. Abundant true mycelia and arthroconidia are formed. On ME agar medium, hyphae and arthroconidia produce clusters of globose to subglobose blastospores, $4.0-6.0 \mu \mathrm{m}$ in diameter. Gametangia are located on opposite sides of septa or on separate hyphae. Asci are subspherical to broadly ellipsoidal, 5-10 $\mu \mathrm{m}$ wide and 6-14 $\mu \mathrm{m}$ long, and contain one to four ascospores. Ascospores are globose to subglobose $3.0-5.0 \mu \mathrm{m}$ in diameter, with an irregular exosporium and gelatinous sheath. The species is homothallic. D-Glucose and galactose are fermented but sucrose, maltose, lactose, raffinose and melibiose are not. The following carbon compounds are assimilated: D-glucose, galactose, L-sorbose, D-xylose, Darabinose (weak), D-ribose (weak), ethanol, glycerol, glucono- $\beta$-lactone, DL-lactic acid, succinic acid and D-galacturonic acid. No growth occurs on sucrose, maltose, cellobiose, trehalose, lactose, melibiose, raffinose, melezitose, inulin, soluble starch, L-arabinose, L-rhamnose, erythritol, ribitol, galactitol, D-mannitol, D-glucitol, methyl $\alpha$-D-glucoside, salicin, 2-ketogluconic acid, 5-ketogluconic acid, citric acid, inositol or D-glucuronic acid. The nitrogen compounds ethylamine, lysine and cadaverine are assimilated but potassium nitrate and sodium nitrite are not. Growth occurs at $27{ }^{\circ} \mathrm{C}$ and is weak at $30{ }^{\circ} \mathrm{C}$ but does not occur at all at $33{ }^{\circ} \mathrm{C}$ on MEYE agar. Growth occurs on vitamin-free medium. No growth occurs on $50 \%$ glucose/yeast extract agar. Growth occurs in the presence of 100 p.p.m. cycloheximide. No growth occurs in the presence of $10 \%$ sodium chloride. No starch-like substances are produced. The diazonium blue $\mathrm{B}$ reaction is negative. Urease activity is negative. The $\mathrm{G}+\mathrm{C}$ content of the nuclear DNA is $40.7 \mathrm{~mol} \%$ (by HPLC).

The type strain, strain SY $-277^{\mathrm{T}} \quad\left(=\mathrm{NBRC} \quad 103136^{\mathrm{T}}\right.$ $=$ CBS $10071^{\mathrm{T}}$ ), was isolated from sediments collected from the deep-sea floor in the Japan Trench, Pacific Ocean.

\section{Acknowledgements}

We thank Professor Marc-André Lachance for his valuable comments and helpful support on the manuscript. This work was funded by grants from the Japan Society for the Promotion of Science (no. 185701000001 and no. 18.06620).

\section{References}

de Hoog, G. S. \& Smith, M. T. (2004). Ribosomal gene phylogeny and species delimitation in Geotrichum and its teleomorphs. Stud Mycol 50, 489-515.

de Hoog, G. S., Smith, M. T. \& Gueho, E. (1986). A revision of the genus Geotrichum and its teleomorphs. Stud Mycol 29, 1-131.

de Hoog, G. S., Smith, M. T. \& Gueho, E. (1998a). Dipodascus de Lagerheim. In The Yeasts, a Taxonomic Study, 4th edn, pp. 181-193. Edited by C. P. Kurtzman \& J. W. Fell. Amsterdam: Elsevier.

de Hoog, G. S., Smith, M. T. \& Gueho, E. (1998b). Galactomyces Redhead \& Malloch. In The Yeasts, a Taxonomic Study, 4th edn, pp. 209-213. Edited by C. P. Kurtzman \& J. W. Fell. Amsterdam: Elsevier.

de Hoog, G. S., Smith, M. T. \& Gueho, E. (1998c). Geotrichum Link: Fries. In The Yeasts, a Taxonomic Study, 4th edn, pp. 574-579. Edited by C. P. Kurtzman \& J. W. Fell. Amsterdam: Elsevier.

Edgcomb, V. P., Kysela, D. T., Teske, A., Gomez, A. V. \& Sogin, M. L. (2002). Benthic eukaryotic diversity in the Guaymas Basin hydrothermal vent environment. Proc Natl Acad Sci U S A 99, 7658-7662.

Fell, J. W., Boekhout, T., Fonseca, A., Scorzetti, G. \& StatzellTallman, A. (2000). Biodiversity and systematics of basidiomycetous yeasts as determined by large-subunit rDNA D1/D2 domain sequence analysis. Int J Syst Evol Microbiol 50, 1351-1371.

Felsenstein, J. (1981). Evolutionary trees from DNA sequences: a maximum likelihood approach. $J$ Mol Evol 17, 368-376.

Felsenstein, J. (1985). Confidence limits on phylogenies: an approach using the bootstrap. Evolution 39, 783-791.

Fujikura, K., Kojima, S., Takaki, K., Maki, Y., Hunt, J. \& Okutani, Y. (1999). The deepest chemosynthesis-based community yet discovered from the hadal zone, $7326 \mathrm{~m}$ deep, in the Japan Trench. Mar Ecol Prog Ser 190, 17-26.

Gadanho, M. \& Sampaio, J. P. (2005). Occurrence and diversity of yeasts in the Mid-Atlantic Ridge hydrothermal fields near the Azores archipelago. Microb Ecol 50, 408-417.

Huelsenbeck, J. P. \& Ronquist, F. (2001). MRBAYES: Bayesian inference of phylogeny. Bioinformatics 17, 754-755.

Komagata, K. \& Nakase, T. (1967). Reitoshokuhin no biseibutsu ni kansuru kenkyu. V. Shihan reitoshokuhin yori bunri shita kobo no seijo (Microbiological studies on frozen foods). Shokuhin Eiseigaku Zasshi 8, 53-57 (in Japanese).

Kurtzman, C. P. \& Fell, J. W. (editors) (1998). The Yeasts: a Taxonomic Study, 4th edn. Amsterdam: Elsevier.

Kurtzman, C. P. \& Robnett, C. J. (1998). Identification and phylogeny of ascomycetous yeasts from analysis of nuclear large subunit (26S) ribosomal DNA partial sequences. Antonie van Leeuwenhoek 73, 331-371.

Kurtzman, C. P. \& Robnett, C. J. (2003). Phylogenetic relationships among yeasts of the 'Saccharomyces complex' determined from multigene sequence analyses. FEMS Yeast Res 3, 417-432.

López-Garcia, P., Vereshchaka, A. \& Moreir, D. (2007). Eukaryotic diversity associated with carbonates and fluid-seawater interface in Lost City hydrothermal field. Environ Microbiol 9, 546-554.

Nagahama, T. (2006). Yeast biodiversity in freshwater, marine and deep-sea environments. In Biodiversity and Ecophysiology of Yeasts (The Yeast Handbook series), pp. 241-262. Edited by C. A. Rosa \& G. Péter. Berlin \& London: Springer.

Nagahama, T., Hamamoto, M., Nakase, T., Takami, H. \& Horikoshi, K. (2001a). Distribution and identification of red yeasts in deep-sea 
environments around the northwest Pacific Ocean. Antonie van Leeuwenhoek 80, 101-110.

Nagahama, T., Hamamoto, M., Nakase, T. \& Horikoshi, K. (2001b). Rhodotorula lamellibrachii sp. nov., a new yeast species from a tubeworm collected at the deep-sea floor in Sagami Bay and its phylogenetic analysis. Antonie van Leeuwenhoek 80, 317-323.

Nakase, T. \& Suzuki, M. (1986). Bullera megalospora, a new species of yeast forming large ballistospores isolated from dead leaves of Oryza sativa, Miscanthus sinensis and Sasa sp. in Japan. J Gen Appl Microbiol 32, 225-240.

Nylander, J. A. A. (2004). MrModeltest version 2. Distributed by the author. Evolutionary Biology Centre, Uppsala University, Uppsala, Sweden.

Posada, D. \& Crandall, K. A. (1998). MODELTEST: testing the model of DNA substitution. Bioinformatics 14, 817-818.

Ronquist, F. \& Huelsenbeck, J. P. (2003). MRBAYES 3: Bayesian phylogenetic inference under mixed models. Bioinformatics 19, 15721574.

Suh, S.-O. \& Blackwell, M. (2006). Three new asexual arthroconidial yeasts, Geotrichum carabidarum sp. nov., Geotrichum histeridarum sp. nov., and Geotrichum cucujoidarum sp. nov., isolated from the gut of insects. Mycol Res 110, 220-228.

Swofford, D. L. (1998). PAUP ${ }^{*}$ : phylogenetic analysis using parsimony (and other methods), version 4. Sunderland, MA: Sinauer Associates.

Tamaoka, J. \& Komagata, K. (1984). Determination of DNA base composition by reversed-phase high-performance liquid chromatography. FEMS Microbiol Lett 25, 125-128.

Thompson, J. D., Higgins, D. G. \& Gibson, T. J. (1994). ClusTAL W: improving the sensitivity of progressive multiple sequence alignments through sequence weighting, position-specific gap penalties and weight matrix choice. Nucleic Acids Res 22, 4673-4680.

Ueda-Nishimura, K. \& Mikata, K. (2000). Two distinct $18 \mathrm{~S}$ rRNA secondary structures in Dipodascus (Hemiascomycetes). Microbiology 146, 1045-1051.

White, T. J., Bruns, T., Lee, S. \& Taylor, J. W. (1990). Amplification and direct sequencing of fungal ribosomal RNA genes for phylogenetics. In PCR Protocols, pp. 315-322. Edited by M. Innis, D. Gelfand, J. J. Sninsky \& T. J. White. San Diego: Academic Press.

Yarrow, D. (1998). Methods for the isolation, maintenance and identification of yeasts. In The Yeasts, a Taxonomic Study, 4th edn, pp. 77-100. Edited by C. P. Kurtzman \& J. W. Fell. Amsterdam: Elsevier. 